DOI: $10.15193 /$ zntj/2019/118/276

\author{
ELŻBIETA MULAWKA, IZABELA DMYTRÓW, \\ ANNA MITUNIEWICZ-MAŁEK, KRZYSZTOF GODULA
}

\title{
RODZAJ KULTURY STARTEROWEJ A WYBRANE CECHY FIZYKOCHEMICZNE SERA TWAROGOWEGO W CZASIE PRZECHOWYWANIA
}

\begin{abstract}
Streszczenie
Analizowano cechy fizykochemiczne, reologiczne (twardość) oraz sensoryczne serów twarogowych kwasowych z mleka krowiego z dodatkiem szczepionki MSO oraz MSO-11 podczas 21 dni chłodniczego przechowywania w temp. $5 \pm 1{ }^{\circ} \mathrm{C}$. Wyprodukowane w warunkach laboratoryjnych próbki doświadczalne zapakowano próżniowo w folię PE/PA o grubości $40 \mu \mathrm{m}$. Analizę serów twarogowych wykonano bezpośrednio po wyprodukowaniu oraz po 3, 7, 14 i 21 dniach przechowywania w warunkach chłodniczych. Badane twarogi każdorazowo poddawano ocenie sensorycznej z zastosowaniem skali porządkowej pięciopunktowej oraz oznaczono w nich zawartość wody i tłuszczu, aktywność wody, kwasowość miareczkową i czynną, wielkość synerezy serwatki oraz twardość. Badane twarogi charakteryzowały się normatywnymi wartościami: zawartości wody i tłuszczu, kwasowości miareczkowej i czynnej oraz twardości. Stwierdzono, że sery twarogowe nie różniły się podstawowym składem chemicznym w czasie przechowywania. Rodzaj kultury starterowej statystycznie istotnie różnicował sery twarogowe pod względem aktywności wody, synerezy serwatki, pH, kwasowości miareczkowej i twardości. Lepszymi cechami sensorycznymi cechował się twaróg wyprodukowany przy użyciu szczepionki MSO. W czasie przechowywania stwierdzono zmniejszenie zawartości wody, przyrost zawartości tłuszczu, zwiększenie ilości serwatki pojawiającej się w opakowaniu próbek doświadczalnych, wzrost kwasowości miareczkowej, zmniejszenie $\mathrm{pH}$ oraz przyrost twardości badanych twarogów.
\end{abstract}

Słowa kluczowe: mleko krowie, twaróg, wskaźniki fizykochemiczne, reologiczne, ocena sensoryczna, kultury starterowe

Mgr inż. E. Mulawka, dr hab. inż. I. Dmytrów, dr hab. inż. A. Mituniewicz-Małek, mgr inż. K. Godula, Zakład Technologii Mleczarskiej i Przechowalnictwa Żywności, Wydz. Nauk o Żywności i Rybactwa, Zachodniopomorski Uniwersytet Technologiczny w Szczecinie, ul. Papieża Pawta VI 3, 71-459 Szczecin. Kontakt: elzbieta.mulawka@zut.edu.pl 


\section{Wprowadzenie}

Podstawą przemysłowej produkcji kwasowych serów twarogowych jest proces koagulacji kazeiny zachodzący w wyniku ukierunkowanej fermentacji pod wpływem bakterii fermentacji mlekowej (ang. Lactic Acid Bacteria, LAB) dodawanych do mleka w postaci kultur starterowych lub zakwasu [66]. Powstający kwas mlekowy powoduje obniżenie $\mathrm{pH}$ do punktu izoelektrycznego kazeiny i powstanie żelu kazeinowego o uporządkowanej strukturze, który w swych przestrzeniach zamyka wodę wraz z rozpuszczonymi w niej składnikami [18]. Otrzymanie prawidłowego skrzepu twarogowego determinuje przebieg dalszych zabiegów technologicznych, a celem stosowania kultur starterowych jest zapoczątkowanie i zapewnienie optymalnej dynamiki fermentacji mlekowej, a także kształtowanie cech jakościowych sera [8, 18, 47, 52]. Charakter przemian zachodzących podczas wyrobu twarogu zależy od składu mikrobiologicznego szczepionki twarogowej oraz parametrów procesu technologicznego.

Celem pracy była ocena wybranych cech fizykochemicznych sera twarogowego kwasowego wyprodukowanego w warunkach laboratoryjnych przy użyciu dwóch różnych kultur starterowych i poddanego przechowywaniu chłodniczemu w temp. $5 \pm 1{ }^{\circ} \mathrm{C}$ przez 21 dni bez dostępu światła.

\section{Material i metody badań}

Przedmiotem prowadzonych badań były 2 rodzaje sera twarogowego kwasowego wyprodukowanego w warunkach laboratoryjnych. Surowcem do jego produkcji było mleko spożywcze zakupione w handlu detalicznym w lutym 2018 r. Zgodnie z deklaracją producenta (Mlekpol, Polska) mleko przerobowe zawierało 3,2 \% thuszczu, 3,2 \% białka i 4,7 \% laktozy. W celu uzyskania skrzepu twarogowego wykorzystano dwie liofilizowane mezofilne kultury starterowe (A i B) pochodzące od tego samego producenta (Biochem S.1., Rzym, Włochy). Użyte startery różniły się składem mikroflory. W skład kultury MSO (A) wchodzą szczepy z gatunków: Lactococcus lactis subsp. lactis oraz Lactococcus lactis subsp. cremoris, natomiast szczepionka MSO-11 (B) zawiera szczepy z gatunków: Lactococcus lactis subsp. lactis, Lactococcus lactis subsp. cremoris, Lactococcus lactis subsp. lactis biovar diacetylactis, Leuconostoc mesenteroides subsp. cremoris. Sery twarogowe wyprodukowano z zachowaniem identycznych parametrów technologicznych, zgodnie z Instrukcją Technologiczną „Sery twarogowe niedojrzewające" [24]. Produkcję twarogów A i B rozpoczynano od zaszczepienia podgrzanego mleka przerobowego (temp. $22-23{ }^{\circ} \mathrm{C}$ ) odpowiednim zakwasem w ilości $5 \%$ (v/v), otrzymanym poprzez ożywienie kultur starterowych. Uaktywnianie szczepionek prowadzono zgodnie z "Instrukcjami technologicznymi produkcji zakwasów", opracowanymi przez Bielecką [2], w mleku regenerowanym w proszku o 10-procentowej zawartości suchej masy. Oba warianty mleka pozostawia- 
no w tej temperaturze do uzyskania skrzepu twarogowego (ok. 10 h). Dojrzały skrzep (pH ok. 4,6) delikatnie podgrzewano w celu oddzielenia od ścian wanny twarożkarskiej, a następnie krojono na prostopadłościany o wymiarach $12 \times 12 \mathrm{~cm}$. Po odwróceniu prostopadłościanów skrzepu poddawano je dogrzewaniu $\left(1{ }^{\circ} \mathrm{C} / 10 \mathrm{~min}\right)$, przy jednoczesnym delikatnym mieszaniu. Proces dogrzewania kończono po osiągnięciu temperatury ok. $40^{\circ} \mathrm{C}$ w centrum gęstwy twarogowej. Uzyskaną gęstwę (po oddzieleniu serwatki na sicie) rozdzielano do jednorazowych worków z elastycznego polietylenu i pozostawiano do ocieknięcia. Otrzymane klinki poddawano prasowaniu za pomocą prasy laboratoryjnej w temp. $10-12{ }^{\circ} \mathrm{C}$, stosując nacisk $1 \mathrm{~kg}$ na $1 \mathrm{~kg}$ masy sera. Czas prasowania wynosił ok. $60 \mathrm{~min}[18,49]$. Twarogi pakowano próżniowo w folię PE/PA o grubości $40 \mu \mathrm{m}$. W systemie pakowania próżniowego stosowano podciśnienie 15 mbar w ciągu 2,5 s oraz opcję ,soft-air" na poziomie 400 mbar. Przechowywaniu chłodniczemu w temp. $5 \pm 1{ }^{\circ} \mathrm{C}$ poddawano po 10 klinków $(300 \mathrm{~g} / \mathrm{szt}$.) sera twarogowego każdego rodzaju. Próbki do analiz pobierano po 3, 7, 14 i 21 dniach chłodniczego przechowywania.

W mleku przerobowym oznaczano kwasowość miareczkową, pH, gęstość, zawartość białka ogólnego i kazeiny oraz zawartość thuszczu [45, 63]. Otrzymane sery oceniano sensorycznie oraz poddawano analizie fizykochemicznej. Oceny sensorycznej dokonywała 5-osobowa grupa degustatorów przeszkolona i posiadająca doświadczenie w wykonywaniu analiz sensorycznych serów twarogowych. Oceniano strukturę, konsystencję, smak, zapach oraz barwę twarogów [43, 44]. W próbkach doświadczalnych oznaczano zawartość tłuszczu metodą techniczną Gerbera w thuszczomierzach van Gulika, zawartość wody metodą techniczną poprzez suszenie w temp. $130{ }^{\circ} \mathrm{C}$ przez 30 min, kwasowość miareczkową w ${ }^{\circ} \mathrm{SH}$ oraz $\mathrm{pH}$ przy użyciu pH-metru $\mathrm{CP}-411$ (Elmetron, Polska) [42]. Oceniano także podatność twarogu na synerezę. Twaróg ważono w opakowaniu (z dokładnością do $0,01 \mathrm{~g}$ ) oraz po jego usunięciu. Opakowanie osuszano papierowym ręcznikiem. Na podstawie różnicy poszczególnych mas ustalano masę serwatki i wyrażano ją jako procent masy twarogu [21, 61, 63]. Oznaczenie twardości wykonywano przy użyciu analizatora tekstury TA.XT plus (Stable Micro Systems, Anglia). Sery penetrowano dwukrotnie na głębokość $20 \mathrm{~mm}$ z prędkością $8 \mathrm{~mm} / \mathrm{s}$ oraz z siłą nacisku 1 G. Średnica trzpienia wynosiła 6 mm [17].

Wszystkie analizy fizykochemiczne oraz ocenę sensoryczną powtórzono w 3 seriach.

Uzyskane wyniki opracowano statystycznie. Istotność różnic między dwiema wartościami średnimi prób niezależnych i zależnych szacowano testami t-Studenta i Cochrana-Coxa. W celu weryfikacji wyników oceny sensorycznej zastosowano test nieparametryczny U Manna-Whitneya, natomiast do oceny istotności wahań analizowanych wskaźników w czasie posłużono się testem $\chi^{2}$. Testowanie prowadzono przy $\mathrm{p} \leq 0,05$. 


\section{Wyniki i dyskusja}

Na podstawie wyników przeprowadzonych analiz potwierdzono, że mleko stanowiące surowiec do wyrobu serów twarogowych charakteryzowało się normatywnymi cechami fizykochemicznymi. Gęstość mleka wynosiła $1,031 \mathrm{~g} / \mathrm{cm}^{3}$, kwasowość miareczkowa kształtowała się na poziomie $6,8^{\circ} \mathrm{SH}$, natomiast jego $\mathrm{pH}$ wynosiło 6,6 . Mleko zawierało średnio 3,13 \% tłuszczu, 3,36 \% białka ogólnego oraz 2,57 \% kazeiny. Cechy jakościowe oraz trwałość twarogów zależą od wielu czynników, tj. od jakości mleka, przebiegu procesu technologicznego, a także warunków przechowywania. Wielu badaczy dowiodło, że surowiec odgrywa kluczową rolę w kształtowaniu cech produktu gotowego oraz wydajności produkcji [1, 15, 20, 23, 55]. Według Szpendowskiego i wsp. [54] sposób przygotowania surowca, przebieg koagulacji kazeiny oraz zastosowanie odpowiedniej techniki separacji masy twarogowej ma istotne znaczenie w produkcji twarogów, które charakteryzują się różnymi cechami fizykochemicznymi.

Wykazano, że korzystniejszymi cechami sensorycznymi charakteryzował się ser B wyprodukowany przy użyciu kultury MSO-11. Mimo że oba warianty twarogu odznaczały się właściwymi cechami sensorycznymi, ich smak i zapach oraz struktura i konsystencja ulegały stopniowemu pogarszaniu w miarę upływu czasu przechowywania. Na obniżenie ogólnej oceny sensorycznej, według oceniających, w największym stopniu wpływało pogorszenie smaku i zapachu próbek doświadczalnych, szczególnie zauważalne po 14 dniach cyklu badawczego (rys. 1). Barwa wszystkich badanych próbek w całym analizowanym okresie pozostawała jednolicie biała. Potwierdzono statystycznie istotny wpływ rodzaju zastosowanej szczepionki twarogowej na smak, zapach a także wygląd i konsystencję twarogów. Wyniki badań własnych nie są zaskakujące, ponieważ niejednokrotnie potwierdzono, że to m.in. użycie odpowiednio dobranych kultur starterowych decyduje o cechach sensorycznych uzyskanego twarogu [13, 18, 25]. Także Żylińska i wsp. [64] twierdzą, że atrakcyjność sensoryczna twarogu stanowi wypadkową jakości mleka, przebiegu procesu produkcyjnego oraz właściwości stosowanych kultur starterowych. Jak podają Samaszko-Fiertek i wsp. [48], szczepy Leuconostoc wykazują zdolność produkcji egzopolisacharydów. Dzięki swym właściwościom reologicznym pozakomórkowe polisacharydy mają właściwości żelujące, utwardzające i zagęszczające. Mogą wpływać na poprawę tekstury, zapobiegać synerezie oraz wpływać na wygląd produktów mleczarskich [27, 57]. Zdolność produkcji śluzowatych polisacharydów wykazuje także Lactococcus lactis subsp. cremoris [58]. Oda i wsp. [36] oraz Gibson i Robertfroid [22] również twierdzą, że niektóre szczepy LAB z rodzaju Lactobacillus, Streptococcus i Lactococcus mają zdolność biosyntezy zewnątrzkomórkowych polisacharydów [35]. Substancje te tworzą pożądane cechy sensoryczne, zwiększają lepkość i zabezpieczają przetwory mleczarskie przed synerezą. W badaniach przeprowadzonych przez Śmietanę i wsp. [55], dotyczących 


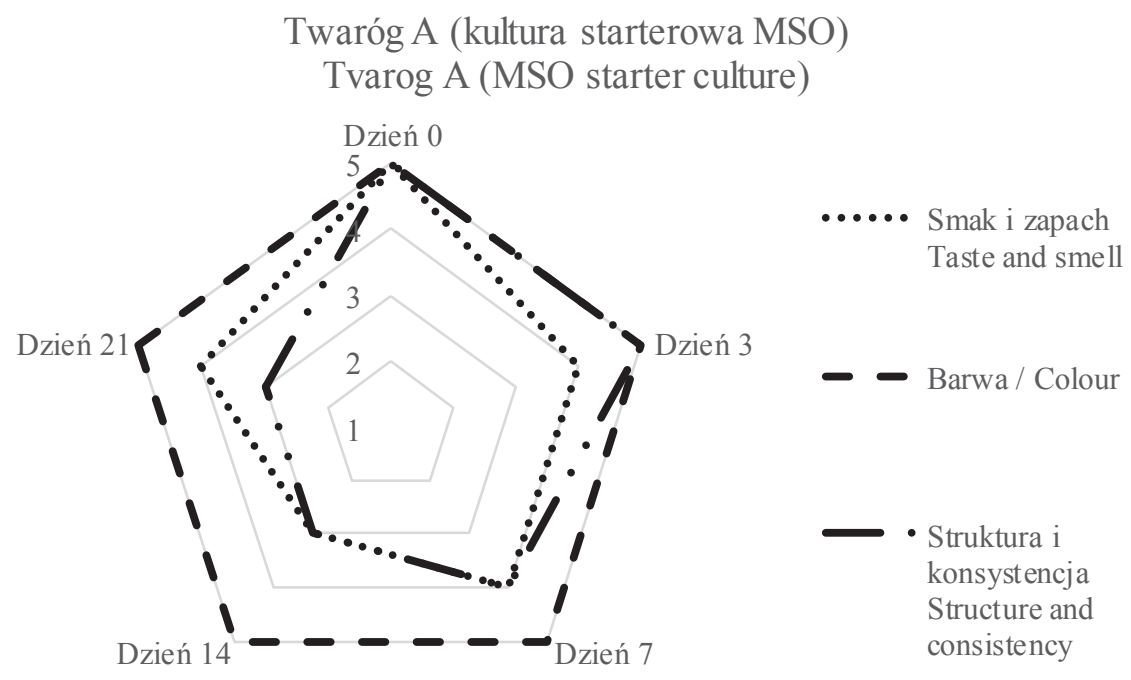

Twaróg B (kultura stsarterowa MSO-11)

Tvarog B (MSO-11 starter culture)
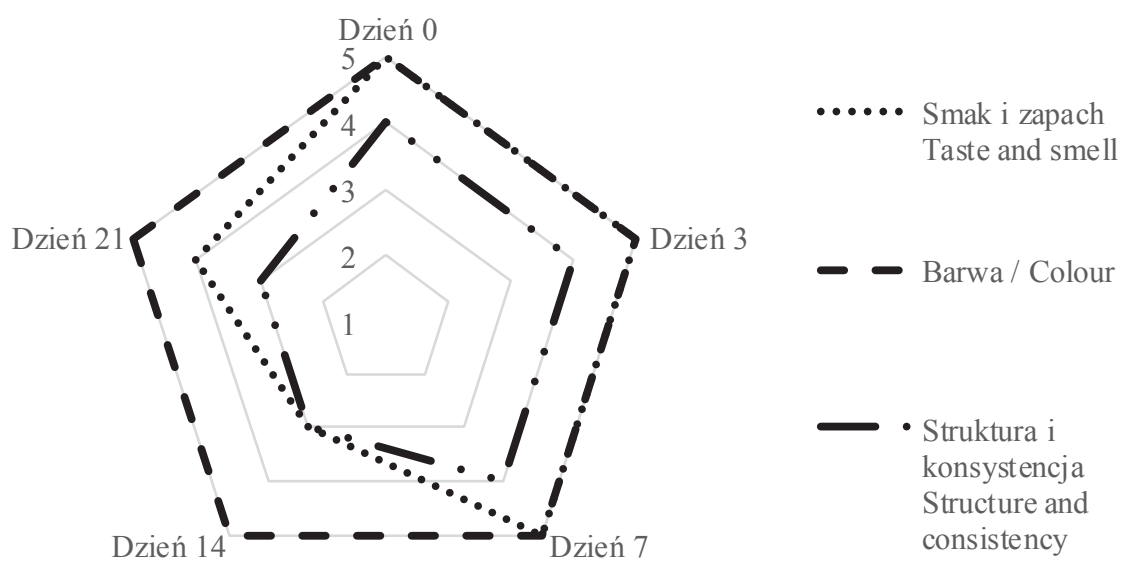

Rys. 1. Wyniki 5-punktowej oceny sensorycznej twarogów A i B przechowywanych w temp. $5 \pm 1{ }^{\circ} \mathrm{C}$ Fig. 1. Results of 5-point scale sensory evaluation of $A$ and $B$ tvarogs during storage at $5 \pm 1{ }^{\circ} \mathrm{C}$

charakterystyki tradycyjnego „polskiego twarogu”, zaobserwowano dużą stabilność cech sensorycznych prób doświadczalnych podczas chłodniczego przechowywania. Według cytowanych autorów wygląd zewnętrzny twarogów pozostawał niezmienny 
w czasie przechowywania, natomiast konsystencja stawała się bardziej zwarta, barwa nieco mniej równomierna, a tekstura bardziej ziarnista. Zwiększyło się także natężenie smaku i zapachu kwaśnego oraz delikatnie cierpkiego. Podobne stanowisko dotyczące wpływu czasu przechowywania na cechy sensoryczne przedstawili również inni autorzy $[7,14,16]$.

W przemysłowej produkcji serów twarogowych najważniejszym dodatkiem technologicznym są kultury starterowe zawierające LAB [64]. Odpowiedni ich dobór warunkuje kształtowanie cech jakościowych i atrakcyjności produktu gotowego [4, 46]. LAB nawet $w$ niewielkim stopniu różniące się aktywnością metaboliczną mogą różnicować przetwory mleczarskie pod względem walorów smakowo-zapachowych. Kultura starterowa MSO-11 charakteryzowała się bogatszym składem jakościowym i, w odróżnieniu od szczepionki MSO, zawierała dodatkowo szczepy Lactococcus lactis subsp. lactis biovar diacetylactis, Leuconostoc mesenteroides subsp. cremoris. Z badań przeprowadzonych przez Ziółkowskiego i wsp. [61] wynika, że obecność w zakwasach szczepów aromatyzujących, tj. L. lactis subsp. lactis var. diacetylactis i Leuconostoc wpływa na kształtowanie pożądanych cech sensorycznych sera. Paciorkowce z rodzaju Lactococcus prowadzą homofermentację z wytworzeniem dużych ilości kwasu mlekowego L(+), z wyjątkiem Lactococcus lactis subsp. lactis biovar diacetylactis, który produkuje mieszaninę racemiczną kwasu mlekowego oraz fermentuje cytryniany do diacetylu. Natomiast paciorkowce rodzaju Leuconostoc to heterofermentatywne bakterie fermentujące laktozę do kwasu mlekowego $\mathrm{D}(-)$, ditlenku węgla i etanolu [60]. Bakterie z rodzaju Lactococcus są dominującą mikroflorą w twarogach - ich liczba wzrasta w czasie fermentacji mleka, osiągając maksimum podczas obróbki skrzepu. W trakcie schładzania twarogu następuje niewielkie zmniejszenie liczby tych bakterii [34]. Starrenburg i Hugenholtz [53] oraz Smit i wsp. [51] podają, że to właśnie LAB metabolizujące cytryniany do diacetylu odgrywają ważną rolę w kształtowaniu cech sensorycznych młodych serów. Mikroorganizmy te produkują także ditlenek węgla, który w przypadku serów twarogowych może być przyczyną powstawania porowatej i nadmiernie nabrzmiałej konsystencji. W badaniach własnych nie zaobserwowano takiego zjawiska. Jak donosi Usajewicz [56], bakterie z rodzaju Leuconostoc powodują również złagodzenie smaku oraz zapachu serów dzięki zdolności przemiany aldehydu octowego, wytwarzanego przez L. lactis subsp. lactis var. diacetylactis, do diacetylu. Diacetyl jest dosyć niestabilny, przede wszystkim gdy w kulturze starterowej są obecne bakterie produkujące enzym o nazwie reduktaza diacetylu. Enzym ten przekształca diacetyl do bezwonnej acetoiny, a następnie do 2,3-butanodionu, prowadząc do stopniowego zaniku pożądanych cech smakowo-zapachowych produktu [59]. Prawdopodobnie to właśnie wspomniane przemiany były przyczyną osłabienia aromatu badanych serów twarogowych w miarę upływu czasu ich przechowywania. 
Potwierdzono w sposób statystycznie istotny, że w całym 21-dniowym okresie przechowywania istotnie większym wyciekiem serwatki charakteryzował się ser B otrzymany poprzez ukwaszenie mleka preparatem MSO-11, natomiast mniejszym twaróg A, do którego produkcji użyto szczepionki MSO (tab. 1). Stwierdzono także istotny przyrost ilości serwatki pojawiającej się w opakowaniach twarogów doświadczalnych. Zwiększającą się w miarę upływu czasu przechowywania próbek doświadczalnych synerezę serwatki zaobserwowali także Karczewska i wsp. [26] w badaniach dotyczących zmian wybranych cech fizykochemicznych twarogów kwasowych w zależności od rodzaju użytego materiału opakowaniowego. Jak podają Litwińczuk i wsp. [29], przyczyn tego zjawiska należy upatrywać w nieodpowiednim rodzaju materiału opakowaniowego (pergamin) oraz źle dobranych parametrach procesu pakowania. Także Śmietana i wsp. [55] twierdzą, że powodem wycieku serwatki w czasie przechowywania twarogu może być stosowanie zbyt dużego podciśnienia podczas pakowania. Wycieku serwatki zaobserwowanego w badaniach własnych nie należy jednak wiązać ze sposobem pakowania próbek doświadczalnych, gdyż zastosowana opcja „soft-air” zapobiega nadmiernemu obkurczaniu foli na produkcie i wymuszonemu wypływaniu serwatki. Natomiast Dmytrów [18] twierdzi, że na ilość wydzielonej serwatki istotny wpływ wywiera rodzaj zastosowanej kultury starterowej. Autorka uważa, że zjawisko to można tłumaczyć tym, że bakterie obecne w szczepionkach twarogowych, dzięki zróżnicowanemu zakwaszaniu środowiska, powodują kurczenie się skrzepu kazeinowego, a tym samym decydują o różnicach wielkości wydzielanej serwatki. Zmiany w układzie koloidalnym twarogu oraz zwiększająca się kwasowość środowiska, wpływająca na wodochłonność białek mleka, mogą także wpływać na zjawisko uwalniania się serwatki. Białka są bowiem czynnikiem wiążącym wodę, zapobiegającym synerezie oraz zwiększającym stabilność produktu [18, 30].

W toku prowadzonych badań stwierdzono statystycznie istotne zmniejszenie zawartości wody oraz towarzyszący mu wzrost zawartości tłuszczu w obu rodzajach twarogu. Nieznacznie większą średnią zawartością wody charakteryzował się ser twarogowy A, do którego produkcji użyto kultury MSO (72,67 \%), natomiast mniejszą twaróg B z dodatkiem szczepionki MSO-11 (72,28 \%). Średnia zawartość thuszczu w serze twarogowym A wynosiła 11,33 \%, podczas gdy w twarogu B 11,68 \% (tab. 1). Dokonana weryfikacja statystyczna nie potwierdziła jednak istotnego wpływu zastosowanego startera na udział wody i tłuszczu w serach twarogowych. Zaobserwowane zjawiska znajdują potwierdzenie w literaturze przedmiotu. Również inni autorzy stwierdzili brak zależności między rodzajem zakwasu a udziałem wody i thuszczu w twarogach $[12,18,28,41,50]$ oraz informowali o zmniejszaniu się zawartości wody w serach twarogowych przechowywanych w warunkach chłodniczych $\left(6{ }^{\circ} \mathrm{C}\right)$ [32]. Pluta i wsp. [41] ocenili wpływ systemu pakowania na jakość twarogów i stwierdzili 


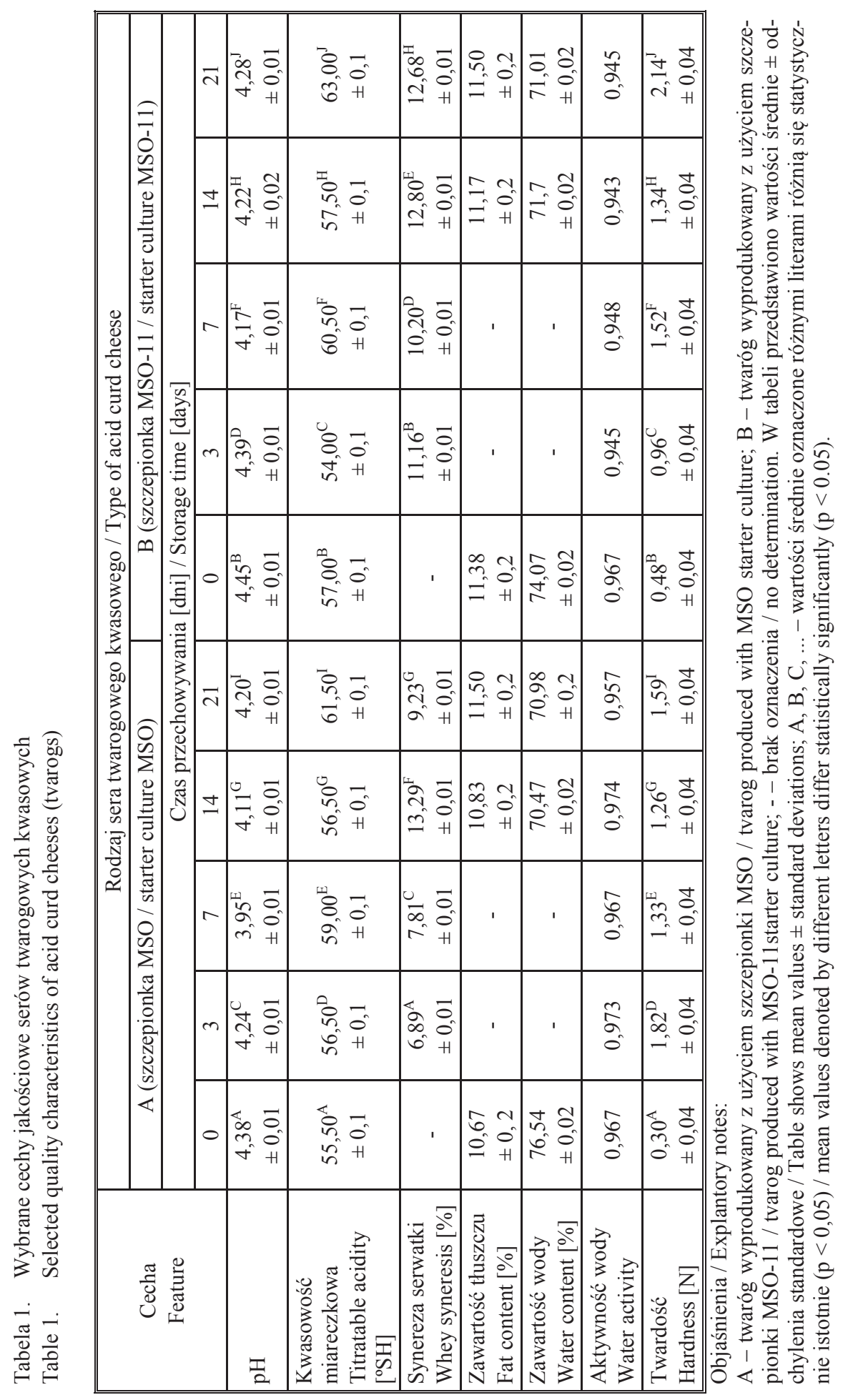


ubytek zawartości wody $\mathrm{w}$ próbkach doświadczalnych zapakowanych próżniowo w modyfikowanej atmosferze, jak i bezpróżniowo podczas trzytygodniowego przechowywania $\left(5 \pm 1{ }^{\circ} \mathrm{C}\right)$. Według cytowanych autorów zmniejszenie zawartości wody spowodowane było wyciekiem serwatki i gromadzeniem się jej w opakowaniu, co zostało również zaobserwowane $\mathrm{w}$ badaniach własnych. Jak podają Mazur [32] oraz Pikul i wsp. [40], zmiany zawartość wody w twarogach są bezpośrednim odzwierciedleniem zjawiska synerezy. Istotny ubytek wody w próbkach doświadczalnych, stwierdzony także w badaniach własnych, najprawdopodobniej był spowodowany częściowo synerezą serwatki, zmieniającą się istotnie w czasie trwania cyklu badawczego. O ubytkach wody w trakcie składowania serów twarogowych donosili także Karczewska i wsp. [26] oraz Dmytrów [18]. O przyroście zawartości tłuszczu, będącym „rekompensatą" ubytku wody, nadmieniali natomiast Dmytrów i wsp. [12]. W literaturze przedmiotu nie odnaleziono dodatkowych informacji na temat zmian zawartości thuszczu w twarogach przechowywanych chłodniczo. W dostępnych źródłach literaturowych pisze się natomiast o stabilizacji zawartości tego składnika [31, 55].

Analizowane sery twarogowe charakteryzowały się kwasowością miareczkową mieszczącą się w zakresie $54 \div 63{ }^{\circ} \mathrm{SH}$ oraz $\mathrm{pH}$ w przedziale $4,11 \div 4,45$. Istotnie większą kwasowością miareczkową, praktycznie w całym ocenianym okresie, charakteryzował się twaróg B (tab. 1). Stwierdzono statystycznie istotny przyrost kwasowości miareczkowej oraz obniżenie wartości $\mathrm{pH}$ w obu wariantach prób doświadczalnych, a zaobserwowane wahania tych parametrów w czasie okazały się statystycznie nieistotne (tab. 2). Wyższymi wartościami $\mathrm{pH}$ w całym analizowanym okresie cechował się twaróg B. Statystyczna weryfikacja uzyskanych wyników potwierdziła istotny wpływ rodzaju kultury starterowej oraz czasu przechowywania na pH twarogów.

Zdolność szybkiego ukwaszania mleka jest jednym z ważniejszych wymagań stawianych kulturom starterowym stosowanym podczas wyrobu serów, w tym także serków twarogowych i twarogów [11]. Dmytrów [18] podaje, że zazwyczaj w czasie pierwszych dni chłodniczego przechowywania sera odnotowuje się zwiększenie kwasowości, a następnie mniej lub bardziej intensywną redukcję wartości tego parametru. Wzrostowi kwasowości miareczkowej towarzyszy zmniejszenie zawartości laktozy. Jak podają Molska i wsp. [34], obniżenie kwasowości twarogów może wynikać między innymi z proteolizy białka i tworzenia zjonizowanych grup. Wraz z upływem czasu przechowywania zmienia się aktywność enzymów bakteryjnych, a przemianom ulegają także białka. Mikš-Krajnik [33] oraz Caplice i Fitzgerald [9] twierdzą, że bakterie Lactococcus lactis mają zdolność rozkładu kazeiny dzięki zakotwiczonej w błonie cytoplazmatycznej proteinazie serynowej. Zewnątrzkomórkowo wydzielane enzymy zakotwiczone w błonach komórkowych kultur starterowych uważane są za główne źródło peptydaz w serach, które biorą udział w hydrolizie oligopeptydów. Komórki 


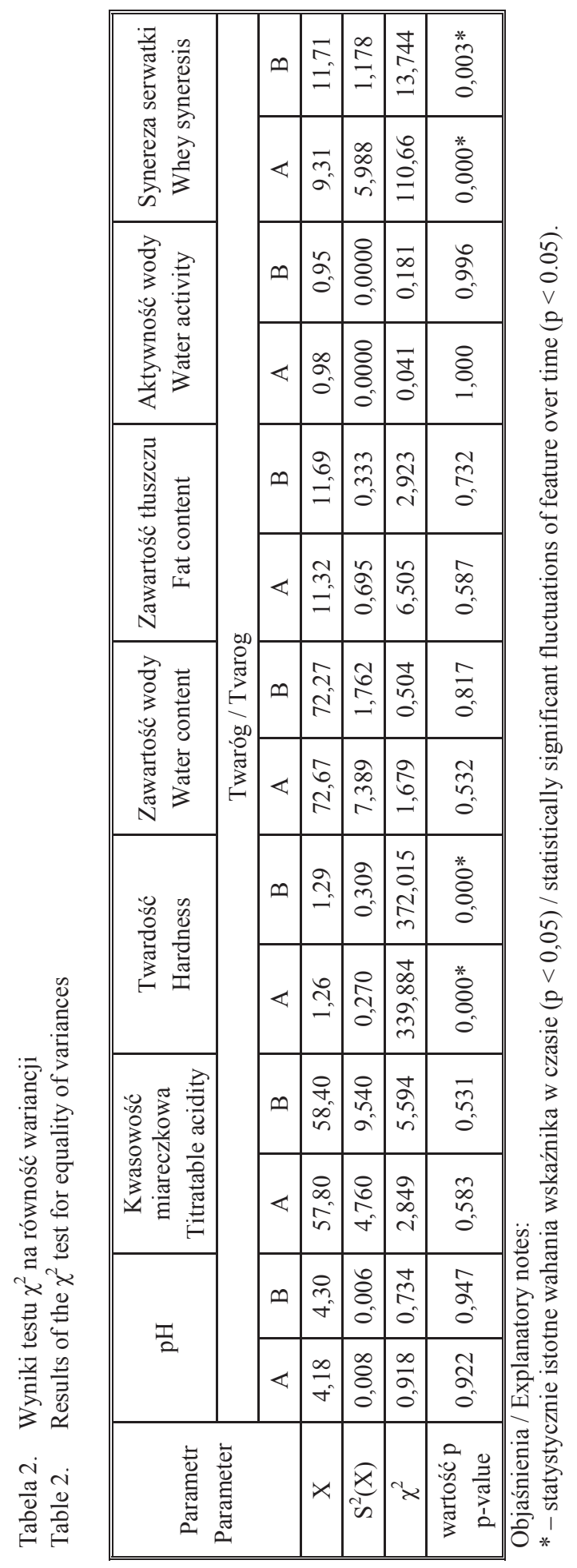


bakterii fermentacji mlekowej ulegają stopniowej lizie, uwalniając enzymy wewnątrzkomórkowe, które także w różnym zakresie wpływają na rozkład składników sera. Pluta i wsp. [41] thumaczyli redukcję kwasowości miareczkowej serów twarogowych zahamowaniem rozwoju, a nawet częściowym wymieraniem paciorkowców mlekowych. Także Ziarno i Godlewska [60] podają, że liczba bakterii z rodzaju Lactococcus, będących przeważającą mikroflorą serów twarogowych, ulega zmniejszeniu w trakcie chłodniczego składowania produktu. Wyniki badań własnych nie do końca pozostają w zgodzie z rezultatami badań opisanymi wyżej, gdyż w przypadku obu rodzajów twarogu trzytygodniowy okres przechowywania w warunkach chłodniczych wiązał się ze zwiększaniem ich kwasowości miareczkowej. Jak wynika z literatury przedmiotu, przyrost kwasowości serów w czasie przechowywania jest wynikiem aktywności kwaszącej LAB, dodanych do mleka przerobowego w postaci szczepionki, które pozostają aktywne także w czasie przechowywania twarogów. Zdolność kultur starterowych do fermentowania laktozy do kwasu mlekowego skutkuje wzrostem kwasowości środowiska [34]. Stwierdzone różnice pod względem kwasowości twarogu A i B można tłumaczyć różnicami w składzie szczepionek oraz odmienną aktywnością metaboliczną zawartych $\mathrm{w}$ nich bakterii. Osiągnięcie $\mathrm{pH}$ zbliżonego do punktu izoelektrycznego kazeiny $(4,4 \div 4,6)$ warunkuje prawidłowe krzepnięcie mleka i uzyskanie skrzepu o odpowiedniej zwięzłości [54]. Dmytrów [18] uważa, że o uzyskaniu wymaganej kwasowości środowiska decyduje rodzaj kultury starterowej. Pandey i wsp. [39] twierdzą, że poza zabiegami technologicznymi na ostateczne pH serów może wpływać obecność mikroorganizmów konkurujących i substancji hamujących, występowanie bakteriofagów, aktywność wody oraz pojemność buforowa mleka.

Większą średnią aktywnością wody w czasie przechowywania charakteryzował się ser z dodatkiem kultury starterowej MSO (tab. 1). Mimo przyrostu tego parametru w przypadku twarogu A i jej obniżenia w twarogu $\mathrm{B}$, duża powtarzalność wyników uniemożliwiła statystyczne oszacowanie istotności zaobserwowanych zmian. Aktywność wody będąca termodynamicznym miernikiem potencjału chemicznego wody wpływa na trwałość oraz jakość produktów [4, 38]. Bonczar i wsp. [6] podają, że wskaźnik ten w produktach spożywczych wskazuje na stopień powiązania cząsteczek wody ze składnikami żywności, a w temperaturze powyżej punktu zamarzania zależy głównie od składu produktu [38]. Jej wartości świadczą o możliwości rozwoju mikroorganizmów, co wpływa na trwałość i jakość produktów. Z badań przeprowadzonych przez Ćwiertniewskiego i wsp. [10] wynika, że w przypadku serów twarogowych parametr ten charakteryzuje się wartością $\mathrm{a}_{\mathrm{w}}=0,955$, a ser - trwałością wynoszącą do $48 \mathrm{~h} \mathrm{w}$ temp. $2 \div 10^{\circ} \mathrm{C}$. Pałacha i Makarewicz [37] na podstawie wyników przeprowadzonych badań dotyczących aktywności wody wybranych grup produktów spożywczych podają, że wartość tego parametru w przypadku twarogów mieści się w prze- 
dziale $0,995 \div 0,999$. Rezultaty badań własnych stanowią potwierdzenie informacji zawartych w literaturze przedmiotu (tab. 1).

Cechą istotnie różnicującą sery twarogowe była ich twardość. Wyższe jej wartości mierzono prawie każdorazowo w twarogu wyprodukowanym $\mathrm{z}$ dodatkiem szczepionki MSO-11. Mimo obserwowanych statystycznie istotnych wahań tego parametru (tab. 2) stwierdzono również statystycznie istotny przyrost twardości obu wariantów prób doświadczalnych. Na wynik pomiaru twardości wpływa zwięzłość skrzepu, rozmieszczenie wody w skrzepie oraz jednorodność próbek doświadczalnych. Nawet niewielkie różnice tych parametrów mogły wpływać na zaobserwowane w badaniach własnych wahania twardości w czasie przechowywania. Według Dzwolaka i wsp. [19] to szczepionka starterowa ukierunkowuje procesy fermentacyjne w produkcji sera oraz oddziałuje na tempo synerezy skrzepu. Proces ten wpływa na ostateczną teksturę twarogu, ponieważ właściwe proporcje pomiędzy ilością wapnia związanego z kazeiną (koloidalnego) i wapnia rozpuszczalnego w fazie wodnej determinują jego podstawową strukturę.

Informacje o przyroście twardości twarogów podczas przechowywania publikują Bohdziewicz [3], Dmytrów i wsp. [12, 16] oraz Mazur [31]. Dmytrów i wsp. [16] dowiedli, że właściwości reologiczne twarogów zależą przede wszystkim od zawartości w nich białka oraz wody. Wraz ze zwiększaniem zawartości białka w twarogach zwiększa się ich twardość, natomiast w przypadku większej ilości wody wartość tego wskaźnika ulega zmniejszeniu. Takie same stanowisko przedstawił Mazur [31], który wykazał, że wraz ze zmniejszaniem się zawartości wody w serze twarogowym zwiększa się jego twardość. Analiza wyników badań własnych potwierdza tę tendencję zarówno w przypadku twarogu $\mathrm{A}$, jak i $\mathrm{B}$. Istotny wpływ na teksturę sera wywierają również metody pakowania. Ziółkowski i wsp. [62] twierdzą, że pakowanie próżniowe narusza strukturę twarogu i prowadzi do zmniejszenia twardości twarogu. W badaniach własnych zastosowano opcję „soft-air”, która podczas pakowania serów zapobiegła nadmiernemu obkurczaniu foli na produkcie oraz naruszeniu jego struktury. Wielu autorów twierdzi również, że na ostateczną teksturę twarogu wpływ wywiera rodzaj kultury starterowej $[5,13,19]$. Zwiększające się zakwaszenie środowiska będące wynikiem aktywności metabolicznej kultur starterowych powoduje kurczenie się skrzepu, lokalne naprężenia i uwalnianie serwatki w rezultacie zwiększenie twardości twarogu.

\section{Wnioski}

1. Zastosowane kultury starterowe $\mathrm{w}$ istotny sposób różnicowały sery twarogowe kwasowe pod względem cech sensorycznych, kwasowości miareczkowej i czynnej, wielkości wycieku serwatki i twardości.

2. Rodzaj kultury starterowej nie wpływał na zawartość wody i tłuszczu w próbach doświadczalnych. 
3. Twaróg wyprodukowany poprzez zaszczepienie mleka kulturą starterową MSO-11 odznaczał się korzystniejszymi cechami sensorycznymi, większym wyciekiem serwatki, większą kwasowością miareczkową, wyższym pH i większą twardością.

4. Wyższą aktywność wody w całym okresie badawczym wykazywał ser twarogowy wyprodukowany przy użyciu kultury MSO, duża powtarzalność wyników uniemożliwiła jednak statystyczne oszacowanie istotności zaobserwowanych różnic.

5. Przechowywanie serów twarogowych w warunkach chłodniczych $\left(5 \pm 1{ }^{\circ} \mathrm{C}\right)$ wiązało się z przyrostem ich kwasowości miareczkowej, obniżeniem pH i aktywności wody, wzrostem zawartości thuszczu, a zmniejszeniem zawartości wody oraz zwiększeniem ich twardości.

\section{Literatura}

[1] Baron L., Labastida E., Perea S., Chabiovarri F., Vega C., Vicente M., Torres M., Najera A., Virto M., Santisteban A., Perez-Elortonto F., Albisu M., Salmeron J., Medina C., Torre P., Ibanez C., de Renobales M.: Seasonal change in the composition of bulk ewes milk used for Idiazabal cheese manufacture. Int. Dairy J., 2001, 11, 771-778.

[2] Bielecka M.: Zakwasy mleczarskie. Instrukcje technologiczne produkcji zakwasów. CZSM, Warszawa 1984, s. 31

[3] Bohdziewicz K.: Twaróg - pierwszy świeży ser świata. Przegl. Mlecz., 2009, 2, 4-8.

[4] Bohdziewicz K.: Wpływ transglutaminazy na proces produkcji, wydatek oraz jakość twarogów. Przegl. Mlecz, 2010, 2, 4-9.

[5] Bonczar G., Walczycka M.: Zależności między parametrami chemicznymi a teksturą świeżej i parzonej masy serowej z mleka owczego. Żywność. Nauka. Technologia. Jakość, 2001, 3 (28), 24-31.

[6] Bonczar G., Wszołek M., Walczycka M., Żebrowska A., Maciejowski K.: Wpływ wybranych czynników na aktywność wody i jakość mikrobiologiczną miękkich serów z mleka owczego. Żywność. Nauka. Technologia. Jakość, 2011, 3 (76), 98-108.

[7] Borowski J.: Analiza sensoryczna w zapewnieniu i kontroli jakości wyrobów mleczarskich oraz okresu ich przydatności do spożycia. Przegl. Mlecz., 2006, 6, 177-179.

[8] Candioti M.C., Hynes E., Quiberoni A., Palma S.B., Sabbag N., Zalazar C.A.: Reggianito Argentino cheese: Influence of Lactobacillus helveticus strains isolated from natural whey cultures on cheese making and ripening processes. Int. Dairy J., 2002, 12 (11), 923-931.

[9] Caplice F., Fitzgerald G.F.: Food fermentations: Role of microorganisms in food production and preservation. Int. J. Food Microbiol., 1999, 50, 131-149.

[10] Ćwiertniewski K., Polak E., Egierski K.: Aktywność wody - parametr trwałości produktów spożywczych. Przem. Spoż., 2005, 59 (11), 16-19.

[11] Dal Bello B., Cocolin I., Zeppa G., Field D., Cotter P.D., Hill C.: Technological characterization of bacteriocin producing Lactococcus lactis strains employed to control Listeria monocytogenes in Cottage cheese. Int. J. Food Microbiol., 2012, 153, 58-65.

[12] Dmytrów I., Kryża K., Dmytrów K., Lisiecki S.: Wpływ opakowania na wybrane cechy jakościowe sera twarogowego kwasowego przechowywanego w warunkach chłodniczych. Żywność. Nauka. Technologia. Jakość, 2007, 1 (50), 64-76.

[13] Dmytrów I., Kryża K., Dmytrów K.: The effect of starter inoculation type on selected qualitative attributes of acid curd cheeses [tvarogs] stored under cooling conditions. EJPAU, 2007, 10 (4), 1-4. 
[14] Dmytrów I., Mituniewicz-Małek A., Dmytrów K., Antonowicz J.: Evaluation of selected physicochemical properties of tvarog produced from extender shelf life milk (ESL). Food Sci. Technol., 2009, 12 (3), 01.

[15] Dmytrów I., Mituniewicz-Malek A., Dmytrów K.: Fizykochemiczne i sensoryczne cechy sera twarogowego kwasowego wyprodukowanego z mleka koziego oraz mieszaniny mleka koziego i krowiego. Żywność. Nauka. Technologia. Jakość, 2010, 2 (69), 46-61.

[16] Dmytrów I., Mituniewicz-Małek A., Dmytrów K.: Ocena wybranych wyróżników jakości serków twarogowych kwasowo-podpuszczkowych dostępnych w handlu detalicznym. Chłodnictwo, 2009, 44, 66-73.

[17] Dmytrów I.: Wpływ probiotycznych bakterii kwasu mlekowego na stabilność przechowalniczą kwasowych serów twarogowych. Żywność. Nauka. Technologia. Jakość, 2015, 5 (102), 49-60.

[18] Dmytrów I.: Wybrane czynniki technologiczne jako determinanty jakości sensorycznej i stabilności przechowalniczej serów twarogowych kwasowych. Rozprawa habilitacyjna, ZUT, Szczecin 2012.

[19] Dzwolak I., Przybylski R., Jankowski P., Żuraw J.: Wpływ stosowanego zakwasu roboczego na wydatek sera. Przegl. Mlecz., 2006, 2, 8-10.

[20] Fekadu B., Soryal K., Zeng S., Van Hekken D., Bah B., Villaquiran M.: Changes in goat milk composition during lactation and their effect on yield and quality of hard and semi-hard cheeses. Small Ruminant Res., 2005, 95 (1), 55-63.

[21] Fritzen-Freire C.B., Muller C.M.O., Laurindo J.B., Prudencio E.S.: The influence of Bifidobacterium Bb-12 and lactic acid incorporation on the properties of Minas Frescal cheese. J. Food Eng., 2010, 96, 621-627.

[22] Gibson G.R., Robertfroid M.B.: Dietary modulation of the human colonic microbiota: Introducing the concept of prebiotics. J. Nutrition, 1995, 124, 1401-1412.

[23] Haenlein G.F.W.: Nutritional value of dairy products of ewe and goat milk [on line]. University of Delaware, Newark 2003. http://www.ag.udel.edu/extension/information/goatmgt/gm-10.htm

[24] Instrukcja technologiczna CZSM 342/88. Sery twarogowe niedojrzewające. Warszawa 1988.

[25] Jakuszkowiak A.: Wpływ rodzaju zastosowanej szczepionki twarogowej na wybrane wskaźniki fizykochemiczne kwasowych serów twarogowych przechowywanych w warunkach chłodniczych. Praca magisterska, AR w Szczecinie, Szczecin 2005.

[26] Karczewska D., Pikul J., Płuszka H., Chudy S.: Zmiany wybranych cech fizykochemicznych tradycyjnie pakowanego twarogu w zależności od rodzaju użytego materiału opakowaniowego. Chłodnictwo, 2005, 10, 46-51.

[27] Kumar A.S., Mody K., Jha B.: Bacterial exopolysaccharides - a perception. J. Basic Microbiol., 2007, 47, 103-117.

[28] Kurkowska J.: Wpływ szczepionki twarogowej na wybrane cechy jakościowe sera twarogowego. Praca magisterska. AR w Szczecinie. Szczecin 2007.

[29] Litwińczuk A., Barłowska J., Król J., Nowakowska J., Topyła B.: Jakość serów twarogowych dostępnych w sieci detalicznej Kielc i Lublina. Żywność. Nauka. Technologia. Jakość, 2003, 4 (37) Supl., 251-258.

[30] Lorenzen P.C., Mautner A., Schlimme E.: Effect of enzymatic crosslinking of milk proteins on the resulting properties of yoghurt products. Kiel. Milchwirtsch. Forschungsber., 1999, 51, 89-97.

[31] Mazur J.: Próba normalizacji metodyki badań profilowej analizy tekstury serów. Towarzystwo Wyd. Nauk. Libropolis, Lublin 2013.

[32] Mazur J.: Zmiany tekstury w trakcie przechowywania w różnych warunkach serów twarogowych kwasowych otrzymanych metodą tradycyjną. Inżynieria Rolnicza, 2009, 2 (111), 99-106.

[33] Mikš-Krajnik M.H.: Rola paciorkowców mlekowych i pałeczek propionowych w procesie dojrzewania sera typu szwajcarsko-holenderskiego. Żywność. Nauka. Technologia. Jakość, 2012, 1 (80), 45-59. 
[34] Molska I.: Zarys mikrobiologii mleczarskiej. PWRiL, Warszawa 1988.

[35] Nordmark E.L., Yang Z., Huttunen E., Widmalm G.: Structural studies of an exopolysaccharide produced by Streptococcus thermophilus THS. Biomacromolecules, 2005, 6, 105-108.

[36] Oda M., Hasegawa H., Komatsu S., Kambe M., Tsuchiya F.: Anti-tumor polysaccharide from Lactobacillus sp. Agric. Biol. Chem., 1983, 47, 1623-1625.

[37] Pałacha Z., Makarewicz M.: Aktywność wody wybranych grup produktów spożywczych. Post. Techn. Przetw. Spoż., 2011, 2, 24-29.

[38] Pałacha Z.: Aktywność wody - ważny parametr trwałości żywności. Przem. Spoż., 2008, 4, 22-27.

[39] Pandey P.K., Ramaswamy H.S., St-Gelais D.: Evaluation of pH kinetics during various stages of Cheddar cheese-making from raw, pasteurized, micro-filtered and high-pressure-treated milk. Lebensm.-Wiss. U.-Technol., 2003, 36, 497-506.

[40] Pikul J., Karczewska D., Cais-Sokolińska D., Danków R.: Physicochemical, microbiological and sensory changes occurring in tvarog in Eco Leanand vacuum packed during refrigerated storage. Pol. J. Food Nutr. Sci., 2006, 15 (56), 173-178.

[41] Pluta A., Wnuk B., Ziarno B., Berthold A.: Wpływ systemu pakowania twarogu na jego jakość. Żywność. Nauka. Technologia. Jakość, 2003, 4 (37) Supl., 330-340.

[42] PN-EN ISO 8968-4:2016-06. Mleko i przetwory mleczne. Oznaczanie zawartości azotu. Część 4: Oznaczanie zawartości azotu białkowego i niebiałkowego oraz obliczanie zawartości białka właściwego (Metoda odniesienia).

[43] PN-ISO 22935-2:2013-07. Mleko i przetwory mleczne. Analiza sensoryczna. Część 2: Zalecane metody oceny sensorycznej.

[44] PN-ISO 22935-3:2013-07. Mleko i przetwory mleczne. Analiza sensoryczna. Część 3: Wytyczne do oceny zgodności właściwości cech sensorycznych ze specyfikacjami produktu z zastosowaniem metody punktowej.

[45] PN-ISO 488:2010. Mleko. Oznaczanie zawartości tłuszczu. Tłuszczomierze Gerbera.

[46] Rybka J., Kołakowski P., Fetliński A.: Wymagania dla kultur starterowych do produkcji tradycyjnego twarogu kwasowego. Biul. Inform. Rhodia Food Biolacta., 2000, 20, 3-6.

[47] Samaržija D., Lukač Havranek J., Antunac N., Sikora S.: Characteristic and role of mesophilic lactic cultures. Agriculturae Conspectus Scientificus, 2001, 6 (22), 113-120.

[48] Samaszko-Fiertek J., Kuźma M., Dmochowska B., Ślusarz R., Madaj J.: Egzopolisacharydy bakteryjne - budowa i funkcje. Wiadomości Chemiczne, 2016, 70, 7-8.

[49] Siemianowski K., Szpendowski J., Bohdziewicz K., Kołakowski P.: Wartość odżywcza twarogu kwasowego otrzymanego z mleka zagęszczonego wyparnie oraz metodą ultrafiltracji (UF). Nauki Inżynierskie i Technologie, 2013, 4 (11), 111-119.

[50] Siemianowski K., Szpendowski J., Bohdziewicz K., Kołakowski P., Pawlikowska K., Bardowski J., Chmielewska M., Żylińska J.: Wpływ zawartości suchej masy w mleku na dynamikę ukwaszania oraz cechy jakościowe skrzepu twarogowego. Żywność. Nauka. Technologia. Jakość., 2013, 1 (86), 151-165.

[51] Smit G., Smit B.A., Engels W.J.: Flavour formation by lactic acid bacteria and biochemical flavour profiling of cheese products. FEMS Microbiology Reviews, 2005, 29 (3), 591-610.

[52] Souza C., Saad S.: Viability of Lactobacillus acidophilus La-5 added solely or in co-culture with a yoghurt starter culture and implications on physico-chemical and related properties of Minas fresh cheese during storage. Food Sci. Technol., 2009, 42 (2), 633-640.

[53] Starrenburg M.J., Hugenholtz J.: Citrate fermentation by Lactococcus and Leuconostoc spp. Appl. Environ. Microbiol., 1991, 57 (12), 3535-3540.

[54] Szpendowski J., Salmanowicz J.: Właściwości fizykochemiczne i odżywcze serwatki i permeatu otrzymywanych w czasie produkcji serów twarogowych. Przegl. Mlecz., 2007, 6, 4-6. 
[55] Śmietana Z., Szpendowski J., Bohdziewicz K.: Charakterystyka tradycyjnego "polskiego twarogu" otrzymanego według własnej nowoczesnej techniki i technologii. Przegl. Mlecz., 2003, 4, 126-129.

[56] Usajewicz I.: Mikrobiologia mleka i jego przetworów. W: Mleczarstwo. Tom I. Red. S. Ziajka. Wyd. UWM, Olsztyn 2007, ss. 152-204.

[57] Van Kranenburg R., Boels I.C., Kleerebezem M., de Vos W.M.: Genetic and engineering of microbial exopolysaccharides for food: Approaches for the production of existing and novel polysaccharides. Curr. Opin. Biotechnol., 1999, 10, 498-504.

[58] Welman A.D., Maddox I.S.: Exopolysaccharides from lactic acid bacteria: Perspectives and challenges. Trends Biotechnol., 2003, 21, 269-274.

[59] Zaręba D., Ziarno M.: Mikrobiologia: Kultury bakteryjne do twarogów. Forum Mleczarskie Biznes., 2016, 4 (26), 1-4.

[60] Ziarno M., Godlewska A.: Znaczenie i wykorzystanie bakterii rodzaju Lactococcus w mleczarstwie. Med. Weter., 2008, 64 (1), 35-39.

[61] Ziółkowski T., Panfil-Kuncewicz H., Staniewska K., Szpendowski J.: Durability of tvarogs produced with modified technology and packed with different methods. Pol. J. Nat. Sci., 2004, 2, 163170.

[62] Ziółkowski T., Staniewska K., Panfil-Kuncewicz H.: Metody pakowania a bezpieczeństwo i trwałość twarogów i serów dojrzewających. Przegl. Mlecz., 2003, 7, 269-272.

[63] Zmarlicki Z.: Ćwiczenia z analizy mleka i produktów mlecznych. Wyd. AR. Warszawa 1981, ss. 1179.

[64] Żylińska J., Siemianowski K., Bohdziewicz K., Pawlikowska K., Kołakowski P., Szpendowski J., Bardowski J.K.: Kultury starterowe do produkcji twarogów kwasowych - rola i oczekiwania. Post. Mikrob., 2014, 53 (3), 288-298.

[65] Żywica R., Szpendowski J., Banach J., Jamiołkowski.: Wpływ zmian sezonowych składu chemicznego mleka na wydatek serów twarogowych. Przegl. Mlecz., 2008, 11, 12-16.

\title{
TYPE OF STARTER CULTURE AND SELECTED PHYSICOCHEMICAL CHARACTERISTICS OF CURD CHEESE (TVAROG) DURING STORAGE
}

\author{
S u m m a ry
}

There were analysed physicochemical, rheological (hardness) and sensory properties of acid curd cheese (tvarog) produced from cow's milk with added MSO and MSO-11 starter cultures during a 21-day storage period at $5 \pm 1{ }^{\circ} \mathrm{C}$. The experimental samples, produced under the laboratory conditions, were vacuum-packed in a $40 \mu \mathrm{m}$ thick PE/PA foil. The analysis of curd cheeses (tvarogs) was performed immediately after production and after 3, 7, 14 and 21 days of cold storage. The tvarogs analysed were every time sensory evaluated using a five-point ordinal scale and there were determined: the contents of water and fat, water activity, titratable and active acidity, the amount of whey syneresis and hardness. It was found that during storage the cheeses evaluated did not differ in their basic chemical composition. The type of starter culture significantly differentiated the tvarogs as regards their water activity, whey syneresis, $\mathrm{pH}$, titratable acidity and hardness. The cheese produced using the MSO starter culture was characterized by better sensory characteristics. During storage there were reported: the decrease in the water content, the increase in fat content, the increase in the amount of whey occurring in the packages with experimental samples, the increase in the titratable acidity, the drop in $\mathrm{pH}$ and the increase in the hardness of the tvarogs analysed.

Key words: cow's milk, tvarog, physicochemical characteristics, rheological characteristics, sensory evaluation, starter cultures 